\title{
Allelopathic Effect Abutilon indicum and Parthenium hysterophorus on Seed Germination and Seedling Growth of Wheat
}

\author{
Dr. Rajendra Kumar \\ Lecturer in Botany, Dr. Bhim Rao Ambedkar Govt. College Sri Ganganagar, Rajasthan, India-335001
}

\begin{abstract}
Allelopathic effect of 3\% aqueous extracts of fresh leaves of Abutilon indicum (L.) Sweet and Parthenium hysterophorus $L$. were studied on seed germination and seedling growth of wheat (Triticum aestivum L. variety Raj. 1482).Seeds were allowed to grow in petri-dishes containing 3\% leaf extracts of A. indicum and P.hysterophorus. The results indicated that seedling growth was promoted by A.indicum while suppressed by $P$. hysterophorus. Seed germination was not affected by A.indicum whereas inhibited by $P$. hysterophorus.
\end{abstract}

Keywords: Allelopathic, Seedling growth etc

\section{Introduction}

A successful establishment of a weed in any ecosystem is attributed to several reasons, such as high growth rate, high reproductive potential, adaptive nature and above all interference by resource depletion and allelopathy (Kohil and Rani, 1994). Allelopathy refers the effects of one plant on another due to chemicals released by them, or the breakdown products of their metabolites (Willis, 1994). The allelochemicals are produced by all kinds of plants and plant parts although roots and leaves are mainly responsible for their production and release (Bansal, 1992). Allelopathy plays a major role in influencing the productivity of agroecosystem through inhibitory or stimulatory interactions. Abutilon indicum (L.) Sweet (family: Malvaceae) and Parthenium hysterophorus L. (family: Asteraceae) are prominent weeds of canal irrigated area of North-West Rajasthan. Therefore an experiment was conducted to investigate the allelopathic effect of leaf extracts of A.indicum and P.hysterophorus on seed germination and seedling growth of wheat.

\section{Materials And Methods}

Fresh leaves of A.indicum and P.hysterophorus in its vegetative stage were collected from agricultural field near Government College, Sri ganganagar. Three grams of leaves of A.indicum were macerated in Pestle and Mortar, and added $100 \mathrm{ml}$ of distilled water and left for $24 \mathrm{~h}$ in dark at the room temperature (average during day: $25^{\circ} \mathrm{C}$ ) for extraction. It was filtered thereafter in two layers of filter paper twice. Aqueous extract was obtained as filtrate of the mixture and final volume was adjusted to $100 \mathrm{ml}$, this gave $3 \%$ aqueous extract. The same procedure was repeated for obtaining 3\% aqueous extract of P. hysterophorus. Seeds were soaked in $2 \%$ sodium hypochlorite for 15 minutes and thoroughly washed with distilled water for surface sterilization. The seeds were germinated in distilled water (control) and leaf extracts (A.indicum and P.hysterophorus) in sterilized petri-dishes lined with double blotting papers and kept at room temperature and diffused light during day for one week with three replications. Ten seeds were taken in each replicate. After one week, number of germinated seeds were counted and, the root and shoot length were measured. All seedlings from each petri-dish were oven dried at $70^{\circ} \mathrm{C}$ for $48 \mathrm{~h}$ to get dry weight of seedlings. Significance of the difference in germination, root and shoot length of seedlings under different treatments was tested and compared using Analysis of Variance (ANOVA) by direct method.

\section{Results and Discussion}

The effect of leaf extracts of A.indicum and P.hysterophorus on seed germination and seedling growth of wheat is presented in Table 1. The results indicated that A.indicum significantly increased seedling growth while P.hysterophorus significantly decreased germination and seedling growth. The $\%$ germination was not affected by A.indicum while $\%$ germination was $86 \%$ of control in P.hysterophorus. The root length increased to $153 \%$ of control in A.indicum whereas, it remained only $51 \%$ in P.hysterophorus. In case of shoot the length was $131 \%$ and $69 \%$ of control in A.indicum and P.hysterophorus respectively. Likewise dry weight also increased to $147 \%$ of control in A.indicum while it remained only $65 \%$ of control in P.hysterophorus (Fig. 1).

The present study confirmed the allelopathic potential of $A$. indicum and P.hysterophorus. Tefera (2002) found that the inhibitory allelopathic impact of leaf extract was more powerful in comparison to other vegetative parts. Phytochemical analysis had already reported high accumulation of growth inhibitors in leaves of P.hysterophorus (Kanchan 1975). Earlier works have also reported that foliar leachates of P.hysterophorus reduced root and shoot elongation of rice (Singh and Sangeeta 1991), maize and soyabeans (Bhatt et al. 1994) as well as some common Australian pasture grasses (Adkins and Sowerby 1996). This indicates the availability of the inhibitory chemicals in higher concentration in leaves than in stem and roots (Kanchan and Jayachandra 1980). Srivastava et al. (1985) revealed that aqueous extracts of leaves and inflorescences inhibited the germination and seedling growth of barley and peas. The present study also verified that leaf aqueous extracts of P.hysterophorus exhibited significant 


\section{International Journal of Science and Research (IJSR) \\ ISSN (Online): 2319-7064 \\ Index Copernicus Value (2015): 78.96 | Impact Factor (2015): 6.391}

inhibitory effects on seed germination and seedling growth of wheat. Results indicated that root elongation was affected more than of the shoot (Table 1, Fig. 1). Similar effect of aqueous extract of leaves of P.hysterophorus was reported on Eragostis sp. (Tefera 2002). P.hysterophorus strongly inhibited root elongation which might be due to direct contact of root with the extract and subsequently with inhibitory chemicals as described in earlier works with various crops and weeds (Bhowmik and Doll 1984, Quasem 1995). The inhibitory effect of P.hysterophorus on seed germination and seedling growth of different plant species is due to presence of growth inhibitors (allelochemicals) in the extracts. Rajan (1973) and Kanchan (1975) were the first to report the presence of plant growth inhibitors in P.hysterophorus. This plant releases a number of water soluble allelochemicals such as phenolic acid and sesquiterpene lactones, particularly parthenin (Kanchan 1975, Swaminathan et al., 1990, Stephen and Sowerby 1996). Phenolics found in the leaves also exhibited inhibitory effects on the growth of nitrogen fixing and nitrifying bacteria (Kanchan and Jayachandra 1981). According to Rice (1984) phenolics are the most common and widely distributed water soluble allelochemicals. The escape of these chemicals into the environment occurs through various mechanisms such as leaching from live or dead plant parts, volatilization as well as root exudation (Rice 1984). These chemicals were reported to have had allelopathic potential on various agronomic crops and weeds and vegetable crops. Patil and Hedge (1988) isolated parthenin in pure form from the leaves of P.hysterophorus and demonstrated that this compound significantly decreased germination of barley seeds and adversely affected seedling growth. Whereas A.indicum significantly increased both root length and shoot length. Compared to shoot growth, the stimulation was more in root growth. However it had no effect on $\%$ germination.

\section{Conclusions}

This study indicates inhibitory potential of P.hysterophorus and promotive potential of $A$. indicum on seed germination and seedling growth of wheat. The study also shows that allelopathy has great potential to regulate the growth of crops through secretion of allelochemicals which should be investigated in detail. By adopting eco-friendly techniques harmful impact of hazardous chemicals can be avoided.

\section{References}

[1] Adkins, S.W. \& Sowerby, M.S. 1996. Allelopathic potential of the weed Parthenium hysterophorus L. in Australia. Plant Protection Quarterly. 11: 20-23.

[2] Bansal, G.L. 1992. The science of allelopathy. In: P. Tauro and S.S. Narwal (eds) Allelopathy in agroecosystems. Indian society of allelopathy, Haryana Agricultural University, Hisar, India.

[3] Bhatt, B.P., Chauhan, D.S. \& Todaria, N.P. 1994. Effect of weed leachates on germination and radicle extension of some food crops. Indian Journal of Plant Physiology. 37: 177-179.

[4] Bhowmik, P.C. \& Doll, J.D. 1984. Allelopathic effects of annual weed residues on growth and nutrient uptake of corn and soybeans. Agronomic Journal. 76: 383-388.

[5] Ghosh P.K., Mandal K.G., Hati Kuntal M. 2000. Allelopathic effects of weeds on groundnut (Arachis hypogaea L.) in India - A review. Agricultural Reviews. 21: 66-99.

[6] Kanchan, S.D. 1975. Growth inhibitors from Parthenium hysterophorus L. Current Science. 44: 358359.

[7] Kanchan, S.D. \& Jayachandra. 1980. Allelopathic effects of Parthenium hysterophorus L. IV. Identification of inhibitors. Plant and Soil. 55: 67-75.

[8] Kanchan, S.D. \& Jayachandra. 1981. Effects of Parthenium hysterophorus on nitrogen-fixing and nitrifying bacteria. Canadian Journal of Botany. 59: 199-202.

[9] Kohil, K.K. \& Rani, D. 1994. Parthenium hysterophorus--a review. Research Bulletin (Sci.) Panjab University. 44: 105-149.

[10]Patil, T.M. \& Hedge, B.A. 1988. Isolation and purification of sesquiterpene lactone from the leaves of Parthenium hysterophorus L. - its allelopathic and cytotoxic effets. Current Science. 42: 1178-1181.

[11]Rajan, L. 1973. Growth inhibitors from Parthenium hysterophorus L. Current Science. 42(20): 729-730.

[12] Rice, E.L. 1984. Allelopathy. 2nd edition. Academic Press, Inc, Florida (USA).

[13] Singh, S.P. \& Sangeeta. 1991. Allelopathic potential of Parthenium hysterophorus L. Journal of Agronomy and Crop Science. 167: 201-206.

[14] Srivastava, J.N., Shukla, J.P. \& Srivastava, R.C. 1985. Effect of Parthenium hysterophorus L. extract on the seed germination and seedling growth of barley, pea and wheat. Acta Botanica Indica. 13: 194-197.

[15] Swaminathan, C., Rai, R.S.V. \& Sureshi, K.K. 1990. Allelopathic effects of Parthenium hysterophorus L. on germination and seedling growth of a few multipurpose trees and arable crops. The International Tree Crops Journal. 6: 143-150.

[16] Tefera, T. 2002. Allelopathic effects of Parthenium hysterophorus extracts on seed germination and seedling growth of Eragrostis tef (Zucc.) Trotter, Journal of Agronomy and Crop Science. 188(5): 306310.

[17] Willis, R.J. 1994. Terminology and trends in allelopathy. Allelopathy Journal. 1(1): 6-28.

Table 1: Impact of aqueous extract of leaves of A.indicum and P.hysterophorus on seed germination and seedling growth of wheat

\begin{tabular}{|c|c|c|c|}
\hline Growth parameters & Control & A.indicum & P.hysterophorus \\
\hline Germination $(\%)$ & 94.66 & 94.66 & $86.50^{*}$ \\
\hline Root length $(\mathrm{cm})$ & $5.61 \pm 0.09$ & $8.62^{*} \pm 0.09$ & $2.94^{* *} \pm 0.05$ \\
\hline Shoot length $(\mathrm{cm})$ & $8.03 \underline{ \pm 0}+02$ & $10.53^{* *}+0.04$ & $5.66^{* *+0.06}$ \\
\hline Total dry weight $(\mathrm{g})$ & $0.227 \pm 0.004$ & $0.338^{* *} \pm 0.01$ & $0.136^{* *} \pm 0.002$ \\
\hline
\end{tabular}

Mean \pm SE, * - Significant at 5\% level, ** - Significant at $1 \%$ level

\section{Volume 6 Issue 1, January 2017




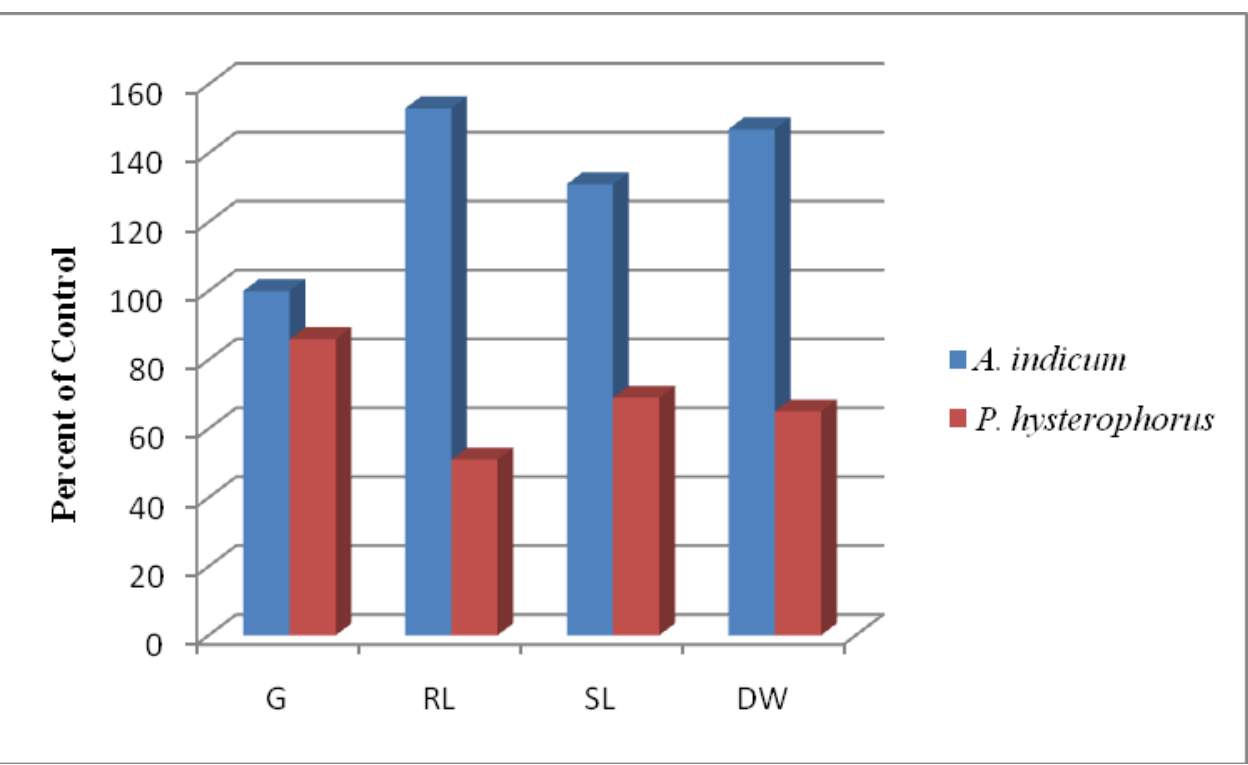

Figure 1: Impact of aqueous extracts of $A$. indicum and $P$.hysterophorus on wheat G - \%Germination, RL- Root length (cm), SL- Shoot length (cm), DW- Dry weight 